\title{
The impact of some commercial yeast strains on aroma compounds and sensorial analysis on two white wine varieties made in PGI Dealurile Olteniei, Romania
}

\author{
Liviu-Gabriel Grigorica ${ }^{1}$, Marius Niculaua ${ }^{2}$, Constantin Bogdan Nechita ${ }^{2}$, Alina-Mihaiela Nistor ${ }^{1}$, and Valeriu V. Cotea ${ }^{1}$ \\ ${ }^{1}$ University of Agricultural Sciences and Veterinary Medicine, 3 Mihail Sadoveanu Alley, Iaşi 700490, Romania \\ ${ }^{2}$ Research Centre for Oenology, Romanian Academy Iasi Branch, 9 Mihail Sadoveanu Alley, Iaşi 700490, Romania
}

\begin{abstract}
Eight wines of Pinot gris and five wines of Sauvignon blanc obtained by fermenting grape juices from PGI Dealurile Olteniei with different commercial selected yeast strains and with indigenous microbiota were compared in terms of sensorial characteristics and their composition in minor volatile aroma compounds. An easy handle methodology with dynamic head-space trap, Gas Chromatography-Mass Spectrometry based, (HS-trap-GC-MS) permits the identification of 49 aroma compounds. The aim of the work was to link these aroma compounds, arranged in different chemical families, with the sensorial analysis and to establish the characteristics of each biotechnology used in the trials so we can find solutions to improve the quality of white wines made in hot climate zone that in time was a traditional area of red wines.
\end{abstract}

\section{Introduction}

Ever since oldest times the hill areas of PGI Dealurile Olteniei have proven excellent conditions for winegrowing and especially for the red wine producing grapes varietis as the great savant Ion Ionescu de la Brad mentioned in 1868 in "Agricultura Română din judeţul Mehedinţi”: “... the greatest benefits from the vineyards come from Blahniţa and Câmpul areas where the famous vineyards of Oreviţa, Rogova, Drância, Oprişorul are located”. In this context it is well known the potential of Golul Drâncei-Mehedinţi for red wine and also for some white wine according to the official task book of the PGI Dealurile Olteniei (2011). The customer preferences for much more fruity-floral style of white wines requires in the last decades improvements in winemaking technology and new approaches in using biotechnologies in winemaking [6,19].

It is well known that the wine aroma can be classified according it origin into three groups: primary (varietal and pre-fermentative included), secondary (fermentative) and tertiary aroma (wine ageing). As the primary aromas cannot be developed into a very worm climate and the tertiary aroma is not so welcomed for fresh \& fruity style white wines the winemakers in the area need to play different strategies in order to achieve as much as possible new and stronger aromas in the wines.

The description of wine aroma is not a simple task for researchers because more than 800 volatile compounds have been identified at a wide range of chemical families and concentration levels [5,12-14]. The combination of varietal and fermentative aromas are the first quality factor for the differentiation of the white wines obtained from a certain variety and in a certain terroir. In the context of a competitive global market some few international grape varieties in some traditional production areas have been intensely studied [1,2]; nevertheless the characteristics of different indigenous varieties or the potential of international varieties in different East-European areas remain still unknown at the present day.

The differences among wines produced from the same grape variety, same PGI, from the same vintage, at the same ripening period and subjected to the same pre-fermentative treatments, but whose fermentations are carried out with different selected yeasts or with indigenous yeasts should be caused to the effect of inoculated yeast that offers undeniable advantages regard to the control and homogeneity of the fermentations [14, 15]. Despite these assertions, some researchers have not found appreciable differences between fermentations carried out with selected yeasts and those performed with indigenous yeasts. In the opinion of some authors it is advisable to use selected yeasts in new wine-growing areas, from early stages of fermentation, while indigenous yeasts are preferable in well-established areas $[4,8,11,16]$.

In recent years, hyphenated techniques have received ever-increasing attention as the principal means to solve complex analytical problems. This way, the use of Gas Chromatography (GC), coupled to Mass Spectroscopy (MS), in combination with dynamic head-space trap (HStrap) showed a powerful integrated platform for the analysis of the volatile compounds present in grape, juice or wine samples $[2,3,18]$.

This work is focused to the application of modern analytical techniques (HS-GC-MS) and sensorial analysis for the differentiation of wines obtained from the same musts (8 wines of Pinot Gris and 5 wines of Sauvignon blanc) using different starter cultures. The aim is to evaluate the influence of the yeasts on the organoleptic 
character in order to find the biotechnological solution that can achieve the proper solution for the commercial approach of the wine style.

\section{Material and methods}

\subsection{Experimental wines production}

In order to conduct this study, grapes of Pinot gris and Sauvignon blanc variety, healthy, at the technological maturity, manually harvested from Oprişor - Golul Drâncei vineyard - PGI Dealurile Olteniei area, were used. The experiment was conducted three vintages: 2013, 2014 and 2015. The grapes were destemmed and crushed. In the case of Sauvignon Blanc the mash was kept for a 6 hours maceration at $10^{\circ} \mathrm{C}$. The obtained must was homogenized and transferred to 5000 litres stainless steel tanks - 8 tanks (in the case of Pinot Gris) and 5 tanks (in the case of sauvignon Blanc) in equal quantities, for batch fermentation. For each year the same enzymatic products for clarification and selected yeasts for controlled fermentation were used. The difference between the variants consisted in the way the clarification was made (gravitational or enzyme-gravitational) and the use or not of various selected yeast strains for the alcoholic fermentation.

For Pinot gris the experimental variants were the following:

PG0 - control, gravitational clarification of the juice, no enzyme treatment, fermentation $18-20^{\circ} \mathrm{C}$, spontaneous fermentation

PG1 - gravitational clarification of the juice, no enzyme treatment, fermentation $16-18^{\circ} \mathrm{C}$, selected yeast $\mathrm{Y} 1$

PG2 - gravitational clarification of the juice, enzyme treatment E1 $2 \mathrm{~g} / \mathrm{hL}$, fermentation $16-18^{\circ} \mathrm{C}$, selected yeast $\mathrm{Y} 1$

PG3 - gravitational clarification of the juice, enzyme treatment E2 $1 \mathrm{~g} / \mathrm{hL}$, fermentation $16-18^{\circ} \mathrm{C}$, selected yeast $\mathrm{Y} 1$

PG4 - gravitational clarification of the juice, enzyme treatment E3 $1 \mathrm{~g} / \mathrm{hL}$, fermentation $1618^{\circ} \mathrm{C}$, selected yeast $\mathrm{Y} 1$

PG5 - gravitational clarification of the juice, enzyme treatment E3 $1 \mathrm{~g} / \mathrm{hL}$, fermentation $16-18^{\circ} \mathrm{C}$, selected yeast $\mathrm{Y} 2$

PG6 - gravitational clarification of the juice, enzyme treatment E3 $1 \mathrm{~g} / \mathrm{hL}$, fermentation $16-18^{\circ} \mathrm{C}$, selected yeast $\mathrm{Y} 3$

PG7 - gravitational clarification of the juice, enzyme treatment E3 $1 \mathrm{~g} / \mathrm{hL}$, fermentation $16-18^{\circ} \mathrm{C}$, selected yeast $\mathrm{Y} 4$

For Sauvignon blanc the experimental variants were the following:

SB0 - control, prefermentative cold maceration at $10^{\circ} \mathrm{C}, 6$ hours, gravitational clarification of the juice, no enzyme treatment, fermentation $18-20^{\circ} \mathrm{C}$, spontaneous fermentation.

SB1 - prefermentative cold maceration at $10^{\circ} \mathrm{C}, 6$ hours, gravitational clarification of the juice, enzyme treatment E1 $2 \mathrm{~g} / \mathrm{hL}$, fermentation $14-16^{\circ} \mathrm{C}$, selected yeast $\mathrm{Y} 2$

SB2 - prefermentative cold maceration at $10^{\circ} \mathrm{C}, 6$ hours, gravitational clarification of the juice, enzyme treatment E1 $2 \mathrm{~g} / \mathrm{hL}$, fermentation $14-16^{\circ} \mathrm{C}$, selected yeast $\mathrm{Y} 3$

SB3 - prefermentative cold maceration at $10^{\circ} \mathrm{C}, 6$ hours, gravitational clarification of the juice, enzyme treatment $\mathrm{E} 12 \mathrm{~g} / \mathrm{hL}$, fermentation $12-14{ }^{\circ} \mathrm{C}$, selected yeast $\mathrm{Y}$

SB4 - prefermentative cold maceration at $10^{\circ} \mathrm{C}, 6$ hours, gravitational clarification of the juice, enzyme treatment E1 $2 \mathrm{~g} / \mathrm{hL}$, fermentation $12-14^{\circ} \mathrm{C}$, selected yeast Y6.

All fermentation were made at controlled temperature $\left(12-18^{\circ} \mathrm{C}\right)$ in Oprisor wine cellar of Carl Reh Winery. The commercial yeast strains were encoded from Y1 to Y6. After the end of alcoholic fermentation (when ethanol content remained constant), a sample of 10 L (glass container) was filtered using BVT-20 filter sheets (Omniafiltri, Italy) and stored in cellar conditions $\left(5-10^{\circ} \mathrm{C}\right)$. All wines were analysed two months after filtration.

\subsection{Gas-chromatographic analysis of volatile compounds}

In order to conduct the determination of the volatiles compounds, all samples were analysed using head space technique with enrichment on a trap material connected to a gas chromatograph with a mass spectrometer detector (Shimadzu HS 20 trap-GC2010plus-MS8040TQ). The system uses helium as carrier gas and the adsorption material in trap as stationary phase is a resin of 2,6diphenylene oxide (TENAX). At $6 \mathrm{~mL}$ of wine were added a mixture of $0.8 \mathrm{~g}$ from the following salts $\mathrm{NaCl}, \mathrm{Na}_{2} \mathrm{SO}_{4}$ and $\mathrm{KH}_{2} \mathrm{PO}_{4}$ in a vial for analysis of vapours (headspace fraction) by the method of salting out. All samples were heated to $70{ }^{\circ} \mathrm{C}$ and shacked at $25 \mathrm{rpm}$ for 5 minutes and then the vials were pressurised to $60 \mathrm{KPa}$ with helium to remove condense. The volatile fraction is transferred in to a Tenax trap at $-10^{\circ} \mathrm{C}$ by a transfer line at $150{ }^{\circ} \mathrm{C}$. Before injection for half a minute the trap is dry purged and then the volatiles are transferred at $280^{\circ} \mathrm{C}$ with a split of $1 / 50$ in to the analytic column. The separation column used is a Phenomenex ${ }^{\circledR}$ ZB WAXplus $60 \mathrm{~m} \times 0.25 \mathrm{~mm}$ ID $\times 0.15 \mu \mathrm{m}$ which is contained in a temperature - controlled oven. Temperature program for separation begins: constant for 3 minute (the total injection time 2 minute) at $82^{\circ} \mathrm{C}$ raped with $3{ }^{\circ} \mathrm{C} / \mathrm{min}$. to $135^{\circ} \mathrm{C}$, maintained for 1 minute, then $7.5^{\circ} \mathrm{C} / \mathrm{min}$. up to $160^{\circ} \mathrm{C}$, maintained for 1 minute and finally raped with $27^{\circ} \mathrm{C} / \mathrm{min}$. to $240^{\circ} \mathrm{C}$ constant for 8 minute (total temperature program 37 minutes). Separation is carried-out at a constant linear velocity of $35 \mathrm{~cm} / \mathrm{s}$ (column flow $1.5 \mathrm{~mL} / \mathrm{min}$ ). The 8040 triple quadrupole is utilised in Q3 (third quadrupole) scan mode from $30-400 \mathrm{Da}$ at $0.1 \mathrm{~s}$ event time $(5000 \mathrm{scan} / \mathrm{sec})$. The ion source interface is maintained at $230{ }^{\circ} \mathrm{C}$ and source at $200^{\circ} \mathrm{C}$. The results are processed qualitatively comparing them to different MS databases available: Nist14, Willey $10^{\text {th }}$, FFNSC and SZTERP. For the quantitative results, all samples are processed by internal standard method relative to 4-methyl-penta-2-ol.

\subsection{Sensory evaluation}

For each vintage a wine sensory evaluation were performed two months after bottling by an expert panel 
Table 1. Analytical parameters of experimental variants, variety Pinot gris, vintages 2013-2015.

\begin{tabular}{|c|c|c|c|c|c|c|c|}
\hline $\begin{array}{c}\text { Experimental } \\
\text { Variant } \\
\text { and Vintage }\end{array}$ & $\begin{array}{c}\text { Alcohol } \\
\% \mathrm{v} / \mathrm{v}\end{array}$ & $\begin{array}{c}\text { Total } \\
\text { Acidity g/L } \\
\mathrm{g} / \mathrm{L} \text { tartaric ac tartaric ac }\end{array}$ & $\begin{array}{c}\text { Reducing } \\
\text { substances } \\
\mathrm{g} / \mathrm{L}\end{array}$ & $\begin{array}{c}\text { Volatile } \\
\text { acidity } \\
\text { acetic ac acacid }\end{array}$ & $\begin{array}{c}\mathrm{SO}_{2} \\
\text { free } \\
\mathrm{mg} / \mathrm{L}\end{array}$ & $\begin{array}{c}\mathrm{SO}_{2} \\
\text { total } \\
\mathrm{mg} / \mathrm{L}\end{array}$ & $\mathrm{pH}$ \\
\hline PG0-2013 & 13.3 & 5.8 & 7.2 & 0.48 & 25 & 110 & 3.42 \\
\hline PG0-2014 & 12.9 & 6.0 & 4.1 & 0.40 & 26 & 105 & 3.29 \\
\hline PG0-2015 & 13.5 & 6.2 & 7.4 & 0.73 & 28 & 118 & 3.48 \\
\hline PG1-2013 & 13.7 & 5.8 & 2.6 & 0.32 & 28 & 109 & 3.40 \\
\hline PG1-2014 & 13.1 & 6.1 & 3.7 & 0.40 & 26 & 107 & 3.33 \\
\hline PG1-2015 & 13.8 & 6.0 & 3.6 & 0.52 & 28 & 120 & 3.45 \\
\hline PG2-2013 & 13.6 & 5.9 & 2.9 & 0.28 & 34 & 109 & 3.42 \\
\hline PG2-2014 & 13.1 & 6.1 & 3.5 & 0.39 & 24 & 105 & 3.27 \\
\hline PG2-2015 & 13.8 & 6.2 & 3.7 & 0.49 & 34 & 120 & 3.43 \\
\hline PG3-2013 & 13.7 & 5.8 & 2.6 & 0.29 & 32 & 111 & 3.42 \\
\hline PG3-2014 & 13.0 & 6.0 & 3.4 & 0.39 & 27 & 105 & 3.31 \\
\hline PG3-2015 & 13.7 & 6.1 & 2.7 & 0.47 & 35 & 117 & 3.48 \\
\hline PG4-2013 & 13.7 & 5.8 & 3.4 & 0.26 & 34 & 109 & 3.44 \\
\hline PG4-2014 & 13.1 & 6.1 & 3.3 & 0.38 & 28 & 104 & 3.30 \\
\hline PG4-2015 & 13.8 & 5.9 & 2.9 & 0.48 & 33 & 122 & 3.47 \\
\hline PG5-2013 & 13.7 & 5.8 & 3.1 & 0.28 & 36 & 108 & 3.43 \\
\hline PG5-2014 & 13.2 & 6.1 & 3.8 & 0.36 & 32 & 108 & 3.32 \\
\hline PG5-2015 & 13.7 & 5.9 & 3.1 & 0.49 & 35 & 120 & 3.49 \\
\hline PG6-2013 & 13.6 & 5.9 & 2.8 & 0.36 & 34 & 109 & 3.42 \\
\hline PG6-2014 & 13.2 & 6.1 & 3.6 & 0.50 & 30 & 104 & 3.30 \\
\hline PG6-2015 & 13.8 & 6 & 3.0 & 0.32 & 34 & 119 & 3.47 \\
\hline PG7-2013 & 13.6 & 5.8 & 3.2 & 0.36 & 28 & 106 & 3.44 \\
\hline PG7-2014 & 13.1 & 6.1 & 0.54 & 33 & 122 & 3.46 \\
\hline PG7-2015 & 13.7 & 6.1 & & & \\
\hline
\end{tabular}

Table 2. Analytical parameters of experimental variants, variety Sauvignon blanc, vintages 2013-2015.

\begin{tabular}{|c|c|c|c|c|c|c|c|}
\hline $\begin{array}{c}\text { Experimental } \\
\text { Variant } \\
\text { and Vintage }\end{array}$ & $\begin{array}{c}\text { Alcohol } \\
\% \mathrm{v} / \mathrm{v}\end{array}$ & $\begin{array}{c}\text { Total } \\
\text { acidity } \\
\mathrm{g} / \mathrm{L} \text { tartaric ac tartaric ac }\end{array}$ & $\begin{array}{c}\text { Reducing } \\
\text { substances } \\
\mathrm{g} / \mathrm{L}\end{array}$ & $\begin{array}{c}\text { Volatile } \\
\text { acidity } \\
\mathrm{g} / \mathrm{L} \text { acetic ac aacid }\end{array}$ & $\begin{array}{c}\mathrm{SO}_{2} \\
\text { free } \\
\mathrm{mg} / \mathrm{L}\end{array}$ & $\begin{array}{l}\mathrm{SO}_{2} \\
\text { total } \\
\mathrm{mg} / \mathrm{L}\end{array}$ & $\mathrm{pH}$ \\
\hline SB0 - 2013 & 12.8 & 5.9 & 5.3 & 0.38 & 28 & 111 & 3.34 \\
\hline SB0 - 2014 & 11.8 & 6.1 & 4.8 & 0.45 & 30 & 115 & 3.21 \\
\hline SB0 - 2015 & 13.4 & 6.6 & 3.9 & 0.79 & 32 & 125 & 3.15 \\
\hline SB1 - 2013 & 13.1 & 6.0 & 3.1 & 0.21 & 38 & 109 & 3.35 \\
\hline SB1 - 2014 & 12.0 & 6.1 & 3.3 & 0.34 & 39 & 113 & 3.23 \\
\hline SB1 - 2015 & 13.6 & 6.5 & 3.2 & 0.62 & 39 & 122 & 3.11 \\
\hline SB2 - 2013 & 13.1 & 5.9 & 2.9 & 0.19 & 37 & 108 & 3.32 \\
\hline SB2 - 2014 & 12.1 & 6.2 & 3.4 & 0.36 & 38 & 112 & 3.22 \\
\hline SB2 - 2015 & 13.6 & 6.7 & 3.1 & 0.73 & 38 & 124 & 3.17 \\
\hline SB3 - 2013 & 13.0 & 6.0 & 3.9 & 0.46 & 32 & 110 & 3.34 \\
\hline SB3 - 2014 & 11.9 & 6.0 & 3.7 & 0.52 & 32 & 115 & 3.21 \\
\hline SB3 - 2015 & 13.5 & 6.5 & 3.5 & 0.85 & 34 & 125 & 3.19 \\
\hline SB4 - 2013 & 13.0 & 6.0 & 3.4 & 0.36 & 34 & 109 & 3.33 \\
\hline SB4 - 2014 & 12.0 & 6.1 & 3.5 & 0.35 & 34 & 114 & 3.23 \\
\hline SB4 - 2015 & 13.5 & 6.5 & 3.4 & 0.73 & 36 & 123 & 3.20 \\
\hline
\end{tabular}

of 5 members of Romanian Wine Tasters Association with experience as sensory judges (same members each year). Blind tests were carried out for each grape variety by comparing the control with the variants. Samples were served in ISO glasses and coded with random two digit numbers. Judges were asked to fill two different sheets: one with general attributes of the wines (smell, taste, overall harmony), one with sensory descriptors considered typical for each variety (Pinot Gris: aroma intensity, complexity, fruit aromas, flowers, vegetal, citrus, exotic, mineral; Sauvignon Blanc: aroma intensity and complexity, fruit aromas, flowers, vegetal, citrus, exotic, acacia, elder, green nuts) using marks from 1 to 9 for each sensory descriptor.

\section{Results and discussion}

\subsection{Oenological characteristics}

Tables 1 and 2 lists the values for the basic enological chemical analysis for the two varieties technological variants. Both controls (PG0 and SB0) regardless of vintage showed the lowest ethanol content and the highest values 


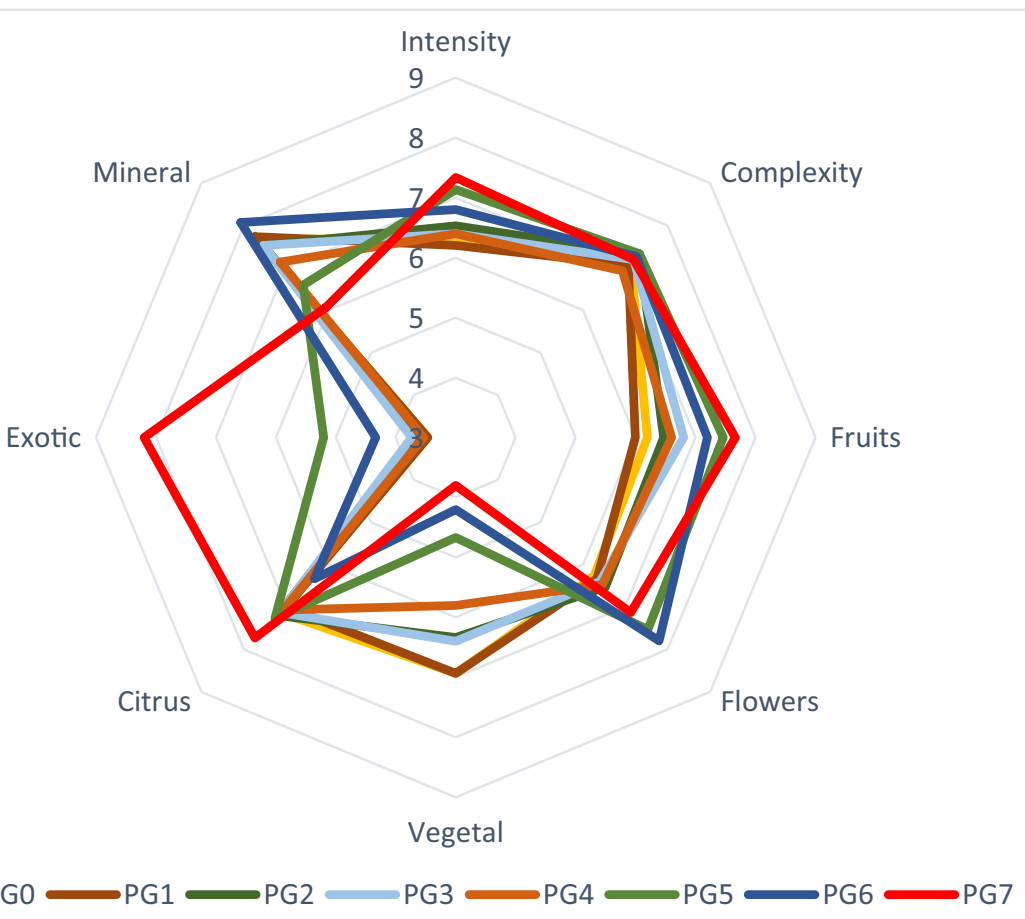

Figure 1. Sensory evaluation of Pinot gris wines fermented with different selected yeasts, PGI Dealurile Olteniei, averages 2013-2015.

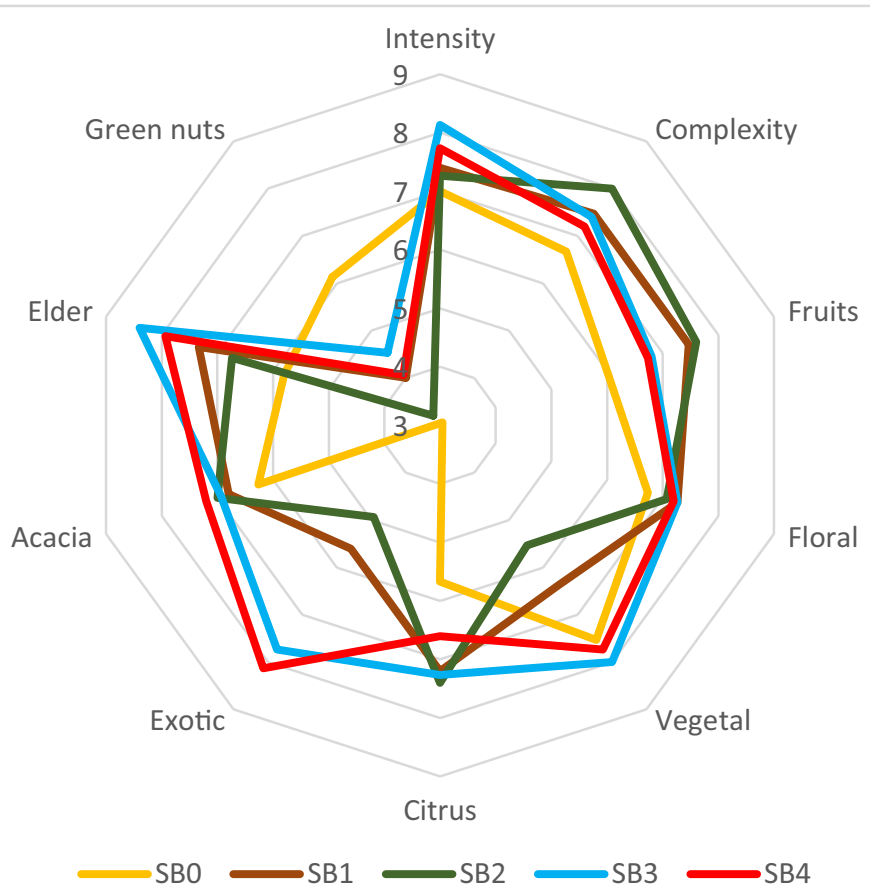

Figure 2. Sensory evaluation of Sauvignon blanc wines fermented with different selected yeasts, PGI Dealurile Olteniei, averages $2013-$ 2015.

of the residual sugars, generally being not considered like dry wines (less than $4 \mathrm{~g} / \mathrm{L}$ residual sugar). Some selected yeast, Y1 and Y2, were able to ferment every vintage untill less residual sugar. The fermentation carried out by selected yeasts showed slight differences among them with respect to all oenological variables quantified. The volatile acidities were systematically bigger in controls comparing with other variants, unconcerned the variety or vintage.

\subsection{Sensory evaluation}

The aim of this test was to evaluate if there were significant differences on the organoleptic characteristics among the young wines obtained using indigenous microbiota and different selected yeast with the goal to improve the overall quality of the white wines.

For Pinot gris as it is shown in Fig. 1 the enzyme used in clarification influences some organoleptic 
Table 3. Sensory evaluation of Pinot gris wines fermented with different selected yeasts, PGI Dealurile Olteniei, results vintage 2015 compared with average 2013-2015.

\begin{tabular}{|c|c|c|c|c|c|c|c|c|}
\hline Variant & Intensity & Complexity & Fruits & Floral & Vegetal & Citrus & Exotic & Mineral \\
\hline PGO- 2015 & 6.20 & 7.40 & 6.40 & 6.60 & 6.60 & 7.20 & 3.80 & 7.60 \\
\hline AVPGO & 6.33 & 7.13 & 6.20 & 6.27 & 6.93 & 7.13 & 3.47 & 7.67 \\
\hline PG1- 2015 & 6.20 & 7.60 & 6.20 & 6.80 & 6.80 & 6.80 & 3.20 & 7.40 \\
\hline AVPG1 & 6.20 & 7.07 & 6.00 & 6.33 & 6.93 & 7.00 & 3.47 & 7.73 \\
\hline PG2- 2015 & 6.40 & 8.20 & 6.60 & 7.00 & 6.40 & 7.20 & 3.60 & 7.20 \\
\hline AVPG2 & 6.53 & 7.33 & 6.47 & 6.53 & 6.33 & 7.20 & 3.67 & 7.53 \\
\hline PG3- 2015 & 6.20 & 8.00 & 6.80 & 6.80 & 6.20 & 7.60 & 4.20 & 7.00 \\
\hline AVPG3 & 6.40 & 7.20 & 6.80 & 6.40 & 6.40 & 7.13 & 3.73 & 7.53 \\
\hline PG4- 2015 & 6.20 & 7.40 & 6.60 & 6.20 & 5.60 & 7.20 & 3.60 & 6.60 \\
\hline AVPG4 & 6.40 & 6.93 & 6.60 & 6.47 & 5.80 & 7.07 & 3.53 & 7.13 \\
\hline PG5- 2015 & 7.20 & 7.80 & 7.40 & 7.60 & 4.20 & 7.60 & 6.20 & 5.80 \\
\hline AVPG5 & 7.13 & 7.33 & 7.47 & 7.53 & 4.67 & 7.27 & 5.20 & 6.60 \\
\hline PG6- 2015 & 6.60 & 7.20 & 7.20 & 8.00 & 4.40 & 6.40 & 4.80 & 8.00 \\
\hline AVPG6 & 6.80 & 7.27 & 7.20 & 7.80 & 4.20 & 6.33 & 4.33 & 8.07 \\
\hline PG7- 2015 & 7.20 & 7.40 & 8.20 & 7.20 & 3.40 & 7.80 & 8.60 & 5.40 \\
\hline AVPG7 & 7.33 & 7.20 & 7.67 & 7.13 & 3.80 & 7.73 & 8.20 & 6.07 \\
\hline
\end{tabular}

Table 4. Sensory evaluation of Sauvignon blanc wines fermented with different selected yeasts, PGI Dealurile Olteniei, results vintage 2015 compared with average 2013-2015.

\begin{tabular}{|c|c|c|c|c|c|c|c|c|c|c|}
\hline Variant & Intensity & Complexity & Fruits & Floral & Vegetal & Citrus & Exotic & Acacia & Elder & Green nuts \\
\hline SB0 - 2015 & 7.00 & 6.60 & 6.40 & 7.00 & 7.60 & 5.20 & 2.60 & 6.00 & 5.40 & 6.20 \\
\hline AV SB0 & 7.00 & 6.67 & 6.00 & 6.73 & 7.53 & 5.67 & 2.93 & 6.27 & 5.80 & 6.13 \\
\hline SB1 - 2015 & 7.40 & 7.80 & 8.20 & 7.60 & 5.40 & 7.80 & 6.20 & 7.00 & 7.60 & 4.20 \\
\hline AV SB1 & 7.40 & 7.47 & 7.47 & 7.27 & 6.40 & 7.20 & 5.60 & 6.80 & 7.33 & 4.00 \\
\hline SB2 - 2015 & 7.60 & 8.20 & 8.60 & 7.20 & 4.20 & 7.00 & 6.20 & 6.40 & 7.20 & 3.60 \\
\hline AV SB2 & 7.27 & 8.00 & 7.60 & 7.07 & 5.53 & 7.40 & 4.93 & 7.00 & 6.73 & 3.20 \\
\hline SB3 - 2015 & 8.40 & 8.00 & 7.40 & 6.80 & 7.80 & 7.20 & 8.40 & 7.40 & 8.40 & 3.80 \\
\hline AV SB3 & 8.13 & 7.40 & 6.80 & 7.27 & 8.00 & 7.27 & 7.73 & 6.93 & 8.40 & 4.53 \\
\hline SB4 - 2015 & 7.80 & 7.40 & 7.80 & 7.60 & 8.20 & 6.80 & 8.20 & 7.80 & 8.20 & 4.20 \\
\hline AV SB4 & 7.73 & 7.20 & 6.73 & 7.20 & 7.73 & 6.60 & 8.13 & 7.20 & 7.93 & 4.07 \\
\hline
\end{tabular}

characteristics (less vegetal, much more fruity/floral aromas) compared with control, but there are not significant differences between different types of enzymes. All controls showed sometimes more aromatic complexity but systematically were less intense compared with the variants fermented with selected yeasts. Among the selected yeasts Y2 and Y4 excels in accentuating some exotic, floral-fruity aromas.

For Sauvignon blanc as it is shown in Fig. 2 the controls are less intense in aromas unconcerned the vintage. Some selected yeasts, Y5 and Y6, showed systematically good marks for exotic aromas, elder and acacia flowers and Y2 were much more consistent in fruit and floral, exotic aromas.

\subsection{Identification of free wine volatile compounds and correlation with wine sensory results}

Identification of maximum 49 relevant volatile wine compounds was performed by using authentic standards NIST08 and Wiley7 mass spectral databases. We were more interested in esters because they are formed by yeasts during the alcoholic fermentation and they are responsible for the fruity aromas of fresh white wines [4]. The results of GC-MS analysis are in Table 5 for Pinot Gris and in Table 6 for Sauvignon Blanc. Table 5 Volatile aroma compounds identified in Pinot gris wines fermented with different selected yeasts, PGI Dealurile Olteniei, vintage 2015 Table 6 Volatile aroma compounds identified in Sauvignon blanc wines fermented with different selected yeasts, PGI Dealurile Olteniei, vintage 2015.

Regarding the correlations between chemical compounds and the results of sensory analysis we can comment the following: for Pinot gris the high mark of exotic notes for PG7 can be explained by higher concentration of ethyl propionate that is usually responsible for tropical aromas [9]; the higher concentration of methyl octanoate (grass aromas) and isoamyl hexanoate (tomato leaf notes) $[17,19]$ explain the bigger marks of vegetal notes for the control PG0; from the other hand the higher concentration of butyl acetate (sensory attributes - citrus) or isobutyl acetate (passion fruit) [10] for variant PG7 have not any correspondence in the wine tasting marks.

For Sauvignon blanc the higher marks for elder and vegetal notes of SB3 and SB4 can be explained by higher concentration of isobutyl acetate and ethyl nonanoate (sensory attributes - cat urine) [7]; the increasing from SB0 to SB4 of the exotic marks can be explained by higher concentration of ethyl propionate. The vegetal notes in SB0 without exotic and elder high marks can be explained by the higher concentration in isoamyl hexanoate without the support of important concentration of isobutyl acetate or ethyl propionate. 
Table 5. Volatile aroma compounds identified in Pinot gris wines fermented with different selected yeasts, PGI Dealurile Olteniei, vintage 2015.

\begin{tabular}{|c|c|c|c|c|c|c|c|c|c|}
\hline \multirow{2}{*}{ Nr. } & \multirow{2}{*}{ Chemical Compound } & \multicolumn{8}{|c|}{ mvali eq SI } \\
\hline & & Pg0 & Pg1 & Pg2 & Pg3 & $\mathrm{Pg} 4$ & Pg5 & Pg6 & Pg7 \\
\hline 1 & 1-propanol & 6.22 & 25.46 & 11.48 & 18.54 & 16.43 & 10.78 & 40.15 & 14.69 \\
\hline 2 & isoamylacetate & 110.79 & 235.11 & 151.24 & 143.44 & 136.31 & 230.89 & 112.14 & 259.66 \\
\hline 3 & 2,6-dimethyl-4-heptanone & 19.61 & 19.16 & 18.54 & 22.29 & 85.77 & 20.78 & 32.86 & 43.89 \\
\hline 4 & ethyl palmitate & 7.46 & 5.78 & 6.65 & 7.88 & 4.89 & 5.06 & 6.07 & 7.41 \\
\hline 5 & 3-methyl-1-butanol & 6043.50 & 6003.59 & 5728.61 & 5942.56 & 6130.44 & 5837.36 & 6121.26 & 6102.52 \\
\hline 6 & ethyl nicotinate & 3.34 & 3.82 & 3.51 & 4.00 & 3.12 & 4.42 & 5.30 & 3.23 \\
\hline 7 & 2,3,3 trimethyl 1,7-octadiene & 59.83 & 57.17 & 64.73 & 80.94 & 42.26 & 45.81 & 24.51 & 70.97 \\
\hline 8 & 3-hexen-1-ol, acetate & 25.66 & 4.57 & 15.54 & 30.39 & 582.99 & 12.06 & 20.50 & 19.40 \\
\hline 9 & 3 methyl 1-pentanol & 591.68 & 576.07 & 564.65 & 569.52 & 1286.18 & 600.23 & 1028.71 & 542.58 \\
\hline 10 & octanoic acid, ethyl ester & 0.98 & 2.62 & 3.22 & 2.87 & 2.98 & 8.17 & 2.86 & 1.42 \\
\hline 11 & isoamyl hexanoate & 42.37 & 13.31 & 18.40 & 22.44 & 18.94 & 22.81 & 23.27 & 20.93 \\
\hline 12 & 3-hexen-1-ol & 2792.63 & 581.45 & 4051.92 & 1451.26 & 1876.14 & 2363.82 & 2536.75 & 2626.27 \\
\hline 13 & isobuthyl acetate & 0.23 & 1.98 & 2.79 & 2.42 & 3.48 & 3.59 & 1.24 & 4.98 \\
\hline 14 & 2-propanone, 1-hydroxy- & 4.79 & 12.95 & 9.65 & 10.05 & 8.76 & 10.24 & 6.89 & 2.88 \\
\hline 15 & 3-pentanol & 106.51 & 262.13 & 133.40 & 192.55 & 20.67 & 81.83 & 48.91 & 281.39 \\
\hline 16 & 1-propanol, 3-etho & 2.46 & 2.45 & 2.98 & 1.74 & 3.25 & 2.37 & 1.82 & 0.98 \\
\hline 17 & ethyl pelargonate & 0.98 & 3.68 & 2.76 & 3.04 & 2.42 & 2.98 & 3.26 & 3.17 \\
\hline 18 & 1-methoxy-3-2-hydroxyethyl nonane & 10.30 & 7.22 & 5.37 & 8.03 & 6.48 & 11.10 & 19.53 & 5.83 \\
\hline 19 & 1-methoxy-3-hydroxymethylheptane & 2.70 & 1.98 & 3.29 & 5.89 & 7.55 & 2.57 & 3.76 & 2.78 \\
\hline 20 & 2,5-dimethyl-1-hepten-4-ol & 7.51 & 12.43 & 15.96 & 14.84 & 15.47 & 12.89 & 13.67 & 10.45 \\
\hline 21 & ammonium oxalate & 17.99 & 15.06 & 18.74 & 8.05 & 3.12 & 11.52 & 12.54 & 23.40 \\
\hline 22 & benzaldehyde & 7.45 & 14.71 & 17.31 & 15.70 & 16.48 & 12.91 & 15.72 & 12.93 \\
\hline 23 & ammonium acetate & 2796.81 & 2481.46 & 3679.23 & 2595.40 & 810.15 & 3847.11 & 3270.45 & 2463.41 \\
\hline 24 & ethyl nonanoate & 3.47 & 10.76 & 12.89 & 18.21 & 16.62 & 12.78 & 14.90 & 14.37 \\
\hline 25 & propanoic acid & 45.52 & 2.97 & 3.04 & 27.48 & 43.02 & 59.44 & 50.96 & 68.28 \\
\hline 26 & 3-methylbutyl ester & 1981.13 & 3176.19 & 3176.02 & 2465.39 & 4348.94 & 2639.88 & 2718.06 & 3175.19 \\
\hline 27 & n-Butyric acid & 23.51 & 24.80 & 21.60 & 22.42 & 26.68 & 44.92 & 55.26 & 21.89 \\
\hline 28 & diethyl ester & 5.64 & 9.55 & 5.78 & 10.85 & 26.35 & 7.90 & 13.97 & 28.36 \\
\hline 29 & isovaleric acid & 126.93 & 78.74 & 124.85 & 103.08 & 66.62 & 93.97 & 144.05 & 112.58 \\
\hline 30 & hexanoic acid & 16.30 & 7.66 & 15.32 & 7.35 & 2.05 & 28.24 & 27.27 & 8.37 \\
\hline 31 & hexanal & 23.29 & 20.24 & 21.16 & 14.66 & 18.76 & 21.42 & 31.71 & 21.72 \\
\hline 32 & 2-phenylethyl & 9.34 & 3.29 & 7.55 & 5.65 & 2.32 & 4.56 & 5.78 & 5.32 \\
\hline 33 & ethyl laurate & 2.76 & 5.62 & 4.60 & 5.76 & 4.24 & 5.20 & 3.14 & 2.78 \\
\hline 34 & pentadecanoic acid 3-methylbutyl ester & 90.90 & 91.29 & 58.06 & 94.72 & 66.43 & 46.95 & 74.52 & 89.45 \\
\hline 35 & hexanoic acid & 269.11 & 430.30 & 349.87 & 316.75 & 583.85 & 304.70 & 312.08 & 388.74 \\
\hline 36 & methyl 3-nonenoate & 14.79 & 12.89 & 16.21 & 12.65 & 24.09 & 16.26 & 19.04 & 15.76 \\
\hline 37 & phenylethyl alcohol & 579.40 & 510.72 & 520.54 & 445.13 & 505.82 & 659.49 & 730.59 & 512.99 \\
\hline 38 & Ethyl trans-2-hexenoate & 3.45 & 1.45 & 1.29 & 2.99 & 2.64 & 2.45 & 1.98 & 3.25 \\
\hline 39 & 1-dodecanol & 369.06 & 391.57 & 369.28 & 312.81 & 842.49 & 395.23 & 407.71 & 361.96 \\
\hline 40 & tetradecanoic acid ethyl ester & 3.31 & 4.30 & 1.98 & 2.70 & 3.96 & 2.76 & 2.45 & 2.41 \\
\hline 41 & ethyl palmitate & 1.12 & 4.49 & 3.52 & 2.61 & 4.12 & 3.98 & 4.23 & 1.34 \\
\hline 42 & octanoic Acid & 4.80 & 14.92 & 12.67 & 13.63 & 14.88 & 18.64 & 12.89 & 15.98 \\
\hline 43 & buthyl acetate & 5.86 & 6.90 & 8.32 & 9.15 & 8.17 & 9.76 & 6.20 & 19.92 \\
\hline 44 & ethyl heptanoate & 558.15 & 250.34 & 322.62 & 355.00 & 495.30 & 735.49 & 879.99 & 441.44 \\
\hline 45 & ethyl propionate & 0.64 & 4.54 & 2.84 & 3.92 & 2.72 & 11.58 & 7.03 & 14.50 \\
\hline 46 & hexadecanoic acid, ethyl ester & 1.20 & 0.98 & 1.22 & 1.48 & 3.37 & 15.18 & 27.62 & 13.31 \\
\hline 47 & n-decanoic acid & 3.40 & 2.25 & 1.83 & 2.43 & 1,12 & 2.62 & 35.82 & 3.56 \\
\hline 48 & methyl octanoate & 33.23 & 6.35 & 16.39 & 21.89 & 21.43 & 15.91 & 16.74 & 8.77 \\
\hline 49 & lauric acid & 619.54 & 798.09 & 489.55 & 550.84 & 558.04 & 579.43 & 645.93 & 467.40 \\
\hline
\end{tabular}

\section{Conclusions}

The HS-GC-MS hyphenated techniques applied to the analysis of wine volatile compounds permits the differentiation of wines obtained from the same must fermented with different selected (commercial) yeasts.

The study showed that it is possible to correlate these results with sensorial analysis marks for both varieties used in this experiment. Not least, during the three vintages study, some selected yeast showed important characteristics from an organoleptic point of view. Y2 and Y4 for Pinot gris and Y2, Y5 or Y6 for Sauvignon blanc can be appropriate solutions for fresh/fruity style wine wines with increased aromas.

The study confirmed that, even in areas with hot climate and not very suitable for good quality white wines, 
Table 6. Volatile aroma compounds identified in Sauvignon blanc wines fermented with different selected yeasts, PGI Dealurile Olteniei, vintage 2015 .

\begin{tabular}{|c|c|c|c|c|c|c|}
\hline \multirow{2}{*}{ Nr. } & \multirow{2}{*}{ Chemical compound } & \multicolumn{5}{|c|}{ mvali eq SI } \\
\hline & & SB0 & SB1 & SB2 & SB3 & SB4 \\
\hline 1 & 1-propanol & 12.34 & 13.56 & 12.89 & 23.56 & 33.59 \\
\hline 2 & isoamylacetate & 108.86 & 135.28 & 144.75 & 123.50 & 81.96 \\
\hline 3 & 1-propanol & 22.14 & 14.33 & 27.18 & 15.04 & 31.75 \\
\hline 4 & 2,6-dimethyl-4-heptanone & 37.19 & 16.24 & 52.54 & 6.59 & 44.40 \\
\hline 5 & 1-butanol, 3-methyl- & 1422.81 & 1359.25 & 1220.57 & 1167.35 & 703.37 \\
\hline 6 & 3-hexen-1-ol & 11.11 & 37.65 & 31.06 & 4.52 & 14.49 \\
\hline 7 & 4-methyl-2-hexanol & 7.36 & 7.63 & 6.20 & 6.48 & 7.97 \\
\hline 8 & 1-pentanol, 3-methyl- & 6.85 & 12.09 & 8.62 & 6.83 & 31.63 \\
\hline 9 & octanoic acid & 2372.05 & 2773.52 & 5300.48 & 2493.99 & 15.74 \\
\hline 10 & 1-hexanol & 11.05 & 25.70 & 14.66 & 8.98 & 40.92 \\
\hline 11 & isoamyl hexanoate & 40.35 & 17.11 & 16.38 & 21.22 & 15.12 \\
\hline 12 & propanoic acid, 2-hydroxy- & 226.16 & 515.32 & 458.92 & 337.82 & 496.13 \\
\hline 13 & isobuthyl acetate & 24.33 & 35.70 & 28.24 & 55.66 & 40.32 \\
\hline 14 & 2-propanone, 1-hydroxy- & 10.36 & 3.37 & 2.24 & 2.74 & 1.42 \\
\hline 15 & ethyl pelargonate & 7.68 & 5.50 & 9.01 & 4.44 & 2.34 \\
\hline 16 & 2,5-dimethyl-1-hepten-4-ol & 11.06 & 9.49 & 8.97 & 8.42 & 12.28 \\
\hline 17 & tridecane, 2-methyl- & 4.38 & 8.11 & 3.78 & 4.86 & 6.87 \\
\hline 18 & 4-heptanol, 2-methyl- & 3.45 & 10.29 & 12.87 & 12.27 & 15.59 \\
\hline 19 & ammonium oxalate & 17.35 & 9.87 & 4.37 & 16.25 & 6.80 \\
\hline 20 & 1-octanol & 5.86 & 7.96 & 12.93 & 5.26 & 8.47 \\
\hline 21 & ethyl decanoate & 2276.79 & 2591.14 & 2943.08 & 1358.20 & 2399.89 \\
\hline 22 & propanoic acid, 2-methyl- & 21.45 & 94.98 & 32.89 & 35.37 & 26.57 \\
\hline 23 & octanoic acid, 3-methylbutyl ester & 4.19 & 5.48 & 4.95 & 5.88 & 6.16 \\
\hline 24 & ethyl nonanoate & 25.88 & 20.46 & 24.28 & 34.88 & 29.73 \\
\hline 25 & n-butyric acid & 76.54 & 152.39 & 112.64 & 49.02 & 30.47 \\
\hline 26 & butanedioic acid, diethyl ester & 42.85 & 80.34 & 30.95 & 37.75 & 18.12 \\
\hline 27 & isovaleric acid & 4.67 & 47.39 & 18.56 & 2.79 & 12.12 \\
\hline 28 & acetic acid & 89.97 & 98.62 & 106.43 & 47.22 & 121.02 \\
\hline 29 & ethyl laurate & 93.28 & 132.86 & 148.75 & 68.27 & 212.93 \\
\hline 30 & pentadecanoic acid, 3-methylbutyl ester & 13.71 & 11.32 & 6.04 & 4.64 & 3.68 \\
\hline 31 & hexanoic acid & 490.79 & 849.21 & 516.30 & 398.80 & 396.54 \\
\hline 32 & benzenemethanol & 3.11 & 10.68 & 3.71 & 2.67 & 4.24 \\
\hline 33 & phenylethyl alcohol & 363.95 & 608.57 & 431.66 & 342.90 & 476.11 \\
\hline 34 & methyl octanoate & 8.85 & 6.00 & 3.93 & 3.45 & 3.64 \\
\hline 35 & ethyl palmitate & 6.86 & 5.99 & 2.77 & 1.12 & 0.96 \\
\hline 36 & ethyl miristate & 2.12 & 5.04 & 21.67 & 31.48 & 28.41 \\
\hline 37 & octanoic Acid & 1352.91 & 2435.94 & 1350.39 & 1214.42 & 1033.28 \\
\hline 38 & hexadecanoic acid, ethyl ester & 13.67 & 41.15 & 28.05 & 87.98 & 75.69 \\
\hline 39 & ethyl heptanoate & 766.85 & 900.33 & 357.31 & 361.38 & 286.84 \\
\hline 40 & ethyl 9-hexadecanoate & 10.71 & 16.59 & 13.88 & 16.10 & 62.50 \\
\hline 41 & 1-hexadecanol & 5.89 & 12.77 & 11.23 & 14.72 & 13.42 \\
\hline 42 & benzoic acid & 9.03 & 0.94 & 1.91 & 2.17 & 0.36 \\
\hline 43 & buthyl acetate & 4.54 & 9.99 & 15.57 & 16.30 & 14.01 \\
\hline 44 & lauric acid & 24.63 & 48.14 & 29.08 & 28.37 & 9.82 \\
\hline 45 & ethyl propionate & 8.34 & 15.41 & 15.83 & 18.30 & 15.98 \\
\hline
\end{tabular}

we can produce good quality fresh/fruity style wines using the correct and adapted biotechnological solution in winemaking.

This work was supported by Doctorate School of USAMV Iasi and the Research Centre for Oenology, Romanian Academy Iasi Branch. The authors thank Carl Reh Winery for the grapes provided and for the use of the winery for the experiments.

\section{References}

[1] G. Antalick, M.-C. Perello \& G. de Revel, American Journal of Enology and Viticulture 65(3), 293-304 (2014)
[2] M. Arbulu, C. Sampedro, A. Sanchez-Ortega, A. Gomez-Caballero, N. Unceta, M.A. Goicole et al. Analytica Chimica Acta 777, 41-48 (2013)

[3] R. Castro, R. Natera, E. Durán, C. Garcia-Barroso, European Food Research Technology 228, 1-18 (2008)

[4] D. Dubourdieu, D., Proceedings of the ASEV 50 ${ }^{\text {th }}$ Anniversary Annual Meeting, 196-203 (2000)

[5] P. X. Etiévant, Wine (Ed. H. Maarse, 1991)

[6] L.G. Grigorica, C. Baduca Campeanu, G. Beleniuc, V. Gheorghiu, Lucrari Stiintifice 53, USAMV Iasi (2010) 
[7] M.G. Lambrechts, I.S. Pretorius, South African Journal of Enology and Viticulture 21, 97-129 (2000)

[8] J. Moreno, C. Millan, J.M. Ortega, M. Medina, Journal of Industrial Microbiology 7, 181-190 (1991)

[9] M.A. Pedroza, A. Zalacain, J.F. Lara, M.R. Salinas, Food Research International 43, 1003-1008 (2010)

[10] I.S. Pretorius, Yeast 16, 675-729 (2000)

[11] J.A. Regodon-Mateos, F. Perez-Nevado, M. RamirezFernandez, Enzime and Microbial technology 40, 151-157 (2006)

[12] P. Reboredo-Rodriguez, C. Gonzales-Barreiro, R. Rial-Otero, B. Cancho-Grande, J. Simal-Gandara, Critical Reviews in Food Science and Nutrition 55, 202-218 (2014)

[13] P. Reboredo-Rodriguez, C. Gonzales-Barreiro, R. Rial-Otero, B. Cancho-Grande, J. Simal-Gandara,
Critical Reviews in Food Science and Nutrition 55, 1051-1071 (2015)

[14] P. Ribéreau-Gayon, Y. Glories, A. Maujean, D. Dubourdieu, Handbook of enology 2, 51-64 (John Wiley \& Sons Ltd., 2006)

[15] P. Romano, C. Fiore, M. Paraggio, M. Caruso, A. Capece, International Journal of Food Microbiology 86, 169-180 (2003)

[16] B. Suarez, R. Pando, N. Fernández, A. González, R. Rodriguez, LWT 38, 455-461 (2005)

[17] K. Šuklje, G. Antalick, A. Buica, A.C. Zelmari, J. Brand, L.M. Schmidtke, M. A. Vivier, Food Chemistry 197, 1073-1084 (2016)

[18] A. Tredoux, A. Villiers, P. Májek, F. Lynen, A. Crouch, P. Sandra, Jour. For Agr. And Food Chem. 56, 4286-4296

[19] F. Vararu, J. Moreno-Garcia, C.I. Zamfir, V.V. Cotea, J. Moreno, Food Chemistry 197, 373-381 (2016) 